\title{
Konduktivitas Listrik Poly(Lactic Acid) dengan Variasi Bahan Isian Karbon: Review
}

\author{
Gabrella Efendy $^{1}$, Indah Dwi Handayani ${ }^{1}$, N. Fauziatul Husni ${ }^{1}$, Siti Habibah ${ }^{1}$, Mujtahid \\ Kaavessina ${ }^{1, a}$ \\ 1 Program Studi Sarjana Teknik Kimia, Fakultas Teknik, Universitas Sebelas Maret \\ E-mail: amkaavessina@staff.uns.ac.id (Corresponding author)
}

\begin{abstract}
Conductive Polymer Nanocomposites (CPC) are materials that are widely used as sensors, photovoltaic cells, capacitors, diodes, and highly flexible energy devices. CPC has several superior properties, including high electrical conductivity, lightweight, corrosion resistance, and good mechanical characteristics. The electrical conductivity of the polymer is obtained and adjusted by adding carbon-based filling materials such as: Carbon Black (CB), Carbon Nanotube (CNT), Graphite, and Graphene. The method of adding filling ingredients can be done by Melt blending and Solvent blending. Melt blending has several advantages, including being easy, practical, inexpensive, and can be applied to various materials. In addition, melt blending is environmentally friendly because there is no organic solvent. Meanwhile, the advantage of Solvent Blending is that it is a stronger mixture because the dispersion is even and better. In the review, the author reviews the electrical properties of poly(lactic acid)-based CPC and various carbon filling materials, namely Carbon Black (CB), Carbon Nanotube (CNT), Graphite, and Graphene. The literature study results show that the electrical conductivity of CPC increases as the composition of the filling material increases. Factors that affect solvent blending are the composition of PLA and stuffing material, operating temperature, stirring speed and time, and the solvent used. While the factors that affect the melt blending are the composition of PLA and stuffing material, operating temperature, extruder speed, and heating time.
\end{abstract}

Keywords: Poly(Lactic Acid), CB, CNT, Graphite, Graphene.

EQUILIBRIUM Volume 5 No.1 July 2021

Online at http://equilibrium.ft.uns.ac.id 


\section{Pendahuluan}

Kebutuhan material konduktif untuk perangkat elektronik seperti sensor, layar sentuh, light emitting diode, electromagnetic interference (EMI) shielding, antistatic packaging, dan supercapacity semakin meningkat seiring dengan pesatnya perkembangan teknologi informasi dan komunikasi. Namun hal tersebut diiringi dengan masalah sampah elektronik yang semakin menumpuk seperti layar tabung monitor, telepon genggam lawas, printer, kulkas, radio, kamera, laptop, hard disk, $\mathrm{CD}$ rom, $\mathrm{PCB}$, dan masih banyak lagi. Barang-barang ini biasanya dibuang begitu saja setelah melewati masa pemakaiannya. Sayangnya, bagian-bagian dari alat elektronik ini tidak bisa terurai secara alamiah dan harus ada penanganan secara khusus untuk pemusnahannya.

Komposit polimer banyak diaplikasikan sebagai struktur bahan dan komponen elektronik karena sifatsifatnya yang ringan, murah, dan tahan air. Namun, polimer memiliki konduktivitas yang relatif kecil tergantung pada jenis-jenisnya [1]. Beberapa polimer memiliki konduktivitas termal yang bagus sehingga berpotensi untuk industri perangkat elektronik [2]. Komposit polimer konduktif terdiri dari matriks polimer non-konduktif dan bahan pengisi konduktif, seperti bubuk logam, bubuk karbon, dan oksida transisi logam.

Poly(Lactic Acid) (PLA) berpotensi sebagai matriks polimer. Polimer yang tergolong biopolimer ini merupakan hasil polimerisasi asam laktat (asam 2-hidroksi propanoat) yang dapat dihasilkan melalui metabolisme mikroorganisme tertentu. Aplikasi utama penggunaan PLA yaitu pada sektor pengemasan [3]. PLA memiliki karakteristik biodegradable, biocompatibility, tahan terhadap pengaruh termal dan kimia. Namun, stabilitas termal yang relatif buruk serta rapuh, membuat PLA terbatas dalam pengembangannya [4]. PLA dengan berat molekul rendah dapat mengalami biodegradasi, dimana mikroorganisme mengasimilasi polimer tersebut [5]. PLA telah disimulasi pada media seperti tanah dan pupuk kompos $\left(25{ }^{\circ} \mathrm{C}<\mathrm{T}<58{ }^{\circ} \mathrm{C}\right)[6,7]$, hasilnya PLA dapat terhidrolisis. Degradabilitas PLA bisa dimodifikasi dengan mengubah mikrostrukturnya [8] atau mencampur dengan polimer lain, aditif, plasticizer, dan beberapa bahan isian anorganik lainnya [9]. PLA bersifat isolator dengan konduktivitas elektrik sebesar $1,39 \times 10^{-12} \mathrm{~S} / \mathrm{cm}$ [10], sehingga dibutuhkan bahan isian untuk menaikkan konduktivitasnya. Konduktivitas elektrik yang tinggi dapat diperoleh dengan menggunakan beberapa nanopartikel konduktif seperti Ag, Au, Pd, CB, CNT, graphite, dan graphene.

Carbon black (CB) merupakan bahan isian yang sering digunakan untuk meningkatkan konduktivitas elektrik, meningkatkan stabilitas dimensi, penstabil cahaya ultraviolet, antioksidan untuk memperpanjang umur karet, serta pigmen atau pewarna. Carbon black bisa digunakan sebagai bahan isian polimer baik tunggal maupun multi fase dengan berbagai macam metode proses, seperti polimerisasi in situ, campuran twin-screw, extrusion mixing, solution mixing, dan sebagainya [11]. CB memiliki kelebihan dapat merata dengan sempurna dalam matriks polimer, sehingga peningkatan sifat konduktivitas elektrik akan merata pada seluruh matriks [12]. Konsentrasi CB dalam proses dispersi akan berbeda-beda menurut polimer pembawanya dengan perbedaan berat molekul, perbedaan metode dan penambahan aditif. Oleh karena itu akan terjadi perbedaan efek pada struktur mikro, rheology, mekanik, dan daya tahan komponen CB [13]. Konduktivitas elektrik karbon tergantung pada proses produksi yang dijalankan, terutama pada area permukaan dan struktur dari $\mathrm{CB}$ yang dipengaruhi oleh proses. Jenis CB yang bagus biasanya digunakan untuk memberikan konduktivitas elektrik pada polimer.

Carbon Nanotube atau CNT juga merupakan bahan isian untuk membuat komposit yang memiliki konduktivitas elektrik dengan konduktivitas elektrik CNT murni sebesar $10^{5}-10^{8} \mathrm{~S} / \mathrm{m}$. CNT merupakan alotrop karbon dengan bentuk silinder berongga yang tersusun dari lembaran graphene bertingkat. CNT dapat berbentuk single walled nanotube (SWNTs), double walled nanotube (DWNTs), atau multi walled nanotube (MWNTs) [14]. CNT mendapat perhatian yang bagus dan menarik sebagai nanomaterial multifungsional karena karakteristik mekanik, thermal, dan elektrik yang luar biasa [15]. PLA dengan penambahan MWNTs sebesar 2 wt $\%$ memiliki properti elektrik terbaik yaitu $3,5 \times 10^{5} \mathrm{~S} / \mathrm{cm}$, hal ini menunjukkan bahwa konduktivitas elektrik yang diperoleh setara dengan polimer komersiil yang menggunakan CB sebagai bahan isiannya [15].

Graphite juga termasuk golongan karbon yang bisa digunakan sebagai bahan pengisi CPC. Graphite murni memiliki panas dan elektrisitas yang bagus sebagai konduktor. Graphite merupakan konversi dari baked carbon menggunakan proses graphitizing yang dimana memanaskan karbon pada temperatur $2.400^{\circ} \mathrm{C}$ hingga $2.800^{\circ} \mathrm{C}$. Graphite mempunyai konduktivitas termal hingga $2 \times 10^{3} \mathrm{~W} / \mathrm{m} . \mathrm{K}$ dan konduktivitas listrik sebesar $10^{6} \mathrm{~S} / \mathrm{m}$ [16]. Pemanfaatan graphite banyak digunakan sebagai bahan isian pensil dengan beberapa variasi kekerasannya dan digunakan juga sebagai campuran clay, pelumas kering pada bagian mesin, bahan dasar pembuatan crucible, elektroda, dan material pada reaktor nuklir untuk mengontrol reaksi fisi nuklir [17].

Jenis karbon lain yang bisa digunakan sebagai bahan isian adalah Graphene. Graphene merupakan atom karbon yang memiliki struktur dua dimensi (2D) dengan keunikan dalam sifat mekanik, kimiawi, dan elektronnya [18]. Graphene memiliki nilai modulus young sebesar 1 TPA dan ultimate strength sebesar $130 \mathrm{GPA}$ 
serta luas permukaan sebesar $2630 \mathrm{~m}^{2} / \mathrm{g}$, menandakan bahwa graphene merupakan material yang kaku dan kuat. Campuran polimer dengan graphene merupakan salah satu aplikasi yang sangat menjanjikan karena meningkatkan sifat-sifat campuran [19]. Penambahan graphene terhadap beberapa variasi polimer telah menunjukan dampak yang positif, yaitu peningkatan daya tahan terhadap degradasi thermal, meningkatkan sifat mekanik, meningkatkan konduktivitas elektrik, dan permeabilitas gas menurun [20]. Oleh karena itu, penambahan graphene memiliki potensi yang signifikan dalam menghasilkan polimer yang bermanfaat dalam perkembangan teknologi serta memiliki nilai yang tinggi karena sifatnya yang ramah lingkungan dan biocompatible.

Penambahan nanopartikel konduktif dengan matriks polimer menghasilkan material baru yang disebut Conductive Polymer Nanocomposites (CPC). CPC memiliki fungsi yang sangat banyak, diantaranya sebagai sensor, sel fotovoltaik, kapasitor, dioda, dan perangkat energi yang sangat mudah meregang [21]. CPC memiliki beberapa sifat unggul, diantaranya konduktivitas elektrik yang tinggi, ringan, tahan korosi, dan memiliki karakteristik mekanis yang bagus. Kemampuan komposit dalam beradaptasi sangat beragam bergantung pada bahan isian dan matriks polimer yang digunakan [22]. Tujuan pada review ini, penulis ingin menyajikan data sifat elektrik dan sifat mekanik CPC berbasis PLA dengan variasi bahan isian berupa 4 jenis karbon yang diperoleh dari berbagai literatur penelitian, sehingga bisa diperoleh kesimpulan pengaruh variasi karbon terhadap sifat CPC.

\section{Metode Sitesis}

\subsection{Melt Blending}

Metode ini memiliki beberapa keunggulan, diantaranya mudah, praktis, murah, serta dapat diaplikasikan pada berbagai bahan dan ramah lingkungan karena tidak ada pelarut organik serta ekonomis pada lingkungan industrial [23].

Faktor yang berpengaruh dalam metode ini adalah konsentrasi, suhu, serta kecepatan extruder. Suhu sangat berpengaruh karena dapat mempengaruhi sifat fisis dan kimia bahan. Suhu disesuaikan dengan titik leleh masing-masing bahan dan tidak melewatinya agar bahan tidak rusak, karena pada proses yang memakai suhu tinggi dapat menyebabkan massa yang hilang pada campuran. Kecepatan extruder juga mempengaruhi homogenitas komposit, semakin rendah kecepatan extruder maka komposit semakin homogen. Proses pada metode melt blending dilakukan dengan mencampur matriks dan bahan isian sesuai komposisi yang telah ditetapkan kemudian memasukkannya ke dalam extruder pada suhu dan kecepatan tertentu, dari extruder akan dihasilkan komposit berbentuk fiber dengan diameter $3 \mathrm{~mm}$.

\subsection{Solvent Blending}

Solvent Blending menggunakan pelarut yang dicampur dengan matriks dan dipanaskan pada suhu tertentu serta diaduk menggunakan sonicator atau magnetic stirrer selama waktu yang telah ditentukan. Solvent blending merupakan metode yang sederhana untuk membentuk pori pada film polimer untuk menghasilkan pori yang terkontrol dengan menggunakan pelarut tunggal. Kelebihan dari metode solvent blending adalah campuran lebih kuat karena disperse yang terjadi merata dan lebih baik [24]. Ada berbagai macam jenis pelarut yang bisa digunakan dalam metode ini, contohnya kloroform dan aseton yang perbedaannya terletak pada hasil karakterisasi menggunakan SEM. Solvent dengan kloroform, komposit berbentuk seperti serat-serat beraturan dan dengan aseton komposit berbentuk seperti gulungan benang tak beraturan [25]. Faktor yang berpengaruh dalam metode ini adalah konsentrasi, pengadukan, suhu, serta jenis pelarut. Hal utama pada metode ini yaitu pemutaran cepat pada pencampuran matriks dengan bahan isian pada konsentrasi tinggi dengan kuantitas yang spesifik [26].

Kelebihan dan kekurangan dari dua metode sintesis CPC disajikan pada Tabel 1

Tabel 1. Kelebihan dan Kekuranga Metode Sintesis CPC

\begin{tabular}{|c|c|c|}
\hline Metode & Kelebihan & Kekurangan \\
\hline Melt Blending & $\begin{array}{ll}\text { - } & \text { Stabilitas termal } \\
& \text { lebih tinggi }\end{array}$ & $\begin{array}{l}\text { - } \begin{array}{l}\text { Bisa merusak sifat } \\
\text { rbeology PLA }\end{array}\end{array}$ \\
\hline
\end{tabular}

Konduktivitas Listrik Poly(Lactic Acid) dengan Variasi Bahan Isian Karbon: Review 


\begin{tabular}{|c|c|c|c|}
\hline & - & $\begin{array}{l}\text { Modulus young } \\
\text { menigkat }\end{array}$ & $\begin{array}{l}\text { - } \quad \text { Mengakibatkan } \\
\text { adanya mass loss }\end{array}$ \\
\hline Solvent Blending & - & $\begin{array}{l}\text { Bahan isian lebih } \\
\text { merata dalam } \\
\text { matriks } \\
\text { Komposit lebih } \\
\text { kuat }\end{array}$ & $\begin{array}{l}\text { - } \quad \text { Stabilitas termal } \\
\text { lebih rendah }\end{array}$ \\
\hline
\end{tabular}

\section{Hasil dan Pembahasan}

\subsection{Sifat Elektrik Komposit}

Nilai konduktivitas elektrik CPC dengan empat macam bahan isian jenis karbon yang diperoleh dari berbagai jurnal penelitian disajikan pada Tabel 2.

Tabel 2. Sifat Elektrik Komposit dengan Matriks PLA dan Bahan Isian Karbon

\begin{tabular}{|c|c|c|c|c|c|}
\hline Metode & $\begin{array}{l}\text { Bahan } \\
\text { Isian }\end{array}$ & Prosedur & $\begin{array}{c}\text { Komposisi } \\
\text { (\% berat) }\end{array}$ & $\begin{array}{l}\text { Konduktivitas } \\
\text { Elektrik } \\
\left({\left.\mathrm{S} . \mathrm{m}^{-1}\right)}^{-1}\right.\end{array}$ & Referensi \\
\hline \multirow{12}{*}{$\begin{array}{l}\text { Solvent } \\
\text { Blending }\end{array}$} & \multirow{8}{*}{$\mathrm{CNT}$} & $\begin{array}{l}\text { Sonication, pelarut kloroform } \\
\left(200^{\circ} \mathrm{C}, 15 \text { menit }\right)\end{array}$ & $\begin{array}{c}3 \\
10\end{array}$ & $\begin{array}{l}1,8 \times 10^{-3} \\
3,5 \times 10^{-3}\end{array}$ & {$[27]$} \\
\hline & & $\begin{array}{l}\text { Solution mixing, pelarut kloroform } \\
\left(180^{\circ} \mathrm{C}\right)\end{array}$ & $\begin{array}{l}0,1-0,4 \\
0,6 \\
1,2\end{array}$ & $\begin{array}{l}2 \times 10^{-13} \\
3 \times 10^{-9} \\
2 \times 10^{-5}\end{array}$ & {$[28]$} \\
\hline & & \multirow{3}{*}{ Sonication di THF } & 1 & $4 \times 10^{-9}$ & \multirow{3}{*}{ [29] } \\
\hline & & & 5 & $1 \times 10^{-9}$ & \\
\hline & & & 7 & $2 \times 10^{-6}$ & \\
\hline & & \multirow{3}{*}{ Solution mixing di THF } & 0,3 & $2 \times 10^{-16}$ & \multirow{3}{*}[30]{} \\
\hline & & & 1 & $3 \times 10^{-9}$ & \\
\hline & & & 3 & $5 \times 10^{-8}$ & \\
\hline & \multirow[t]{2}{*}{ Graphene } & Sonication di DMF $\left(185^{\circ} \mathrm{C}\right)$ & $\begin{array}{c}0,25 \\
1\end{array}$ & $\begin{array}{l}1 \times 10^{-16} \\
1 \times 10^{-6}\end{array}$ & {$[31]$} \\
\hline & & Sonication di DMF $\left(210^{\circ} \mathrm{C}\right)$ & $1,25(\% \mathrm{vol})$ & $6,5 \times 10^{-13}$ & [32] \\
\hline & Graphite & Sonication $\left(60^{\circ} \mathrm{C}, 60\right.$ menit $)$ & $\begin{array}{l}20 \\
25 \\
30\end{array}$ & $60-70 \times 10^{3}$ & [33] \\
\hline & $\mathrm{CB}$ & $\begin{array}{l}\text { PLA/Thymol ( } 95 / 5 \% \text { wt) Magnetic } \\
\text { stirring, pelarut kloroform }\left(60^{\circ} \mathrm{C}, 3\right. \\
\text { jam) }\end{array}$ & $\begin{array}{c}0,5 \\
1 \\
3 \\
5 \\
10 \\
\end{array}$ & $\begin{array}{l}2,37 \times 10^{-9} \\
2,52 \times 10^{-9} \\
3,15 \times 10^{-9} \\
7,88 \times 10^{-9} \\
7,98 \times 10^{-9} \\
\end{array}$ & [10] \\
\hline \multirow{6}{*}{$\begin{array}{l}\text { Melt } \\
\text { Blending }\end{array}$} & \multirow{3}{*}{ CNT } & $\begin{array}{l}\text { Twin-screw extruder }\left(180,215,250^{\circ} \mathrm{C} \text {; }\right. \\
\text { 100, 200, } 500 \mathrm{rpm} ; 5 \text { menit) }\end{array}$ & $\begin{array}{c}1,5 \\
3 \\
5\end{array}$ & $\begin{array}{l}1 \times 10^{-9} \\
1 \times 10^{-2} \\
1\end{array}$ & [34] \\
\hline & & Twin-screw extruder $\left(180^{\circ} \mathrm{C}, 5\right.$ menit $)$ & $\begin{array}{l}2 \\
3 \\
5\end{array}$ & $\begin{array}{c}4 \\
14 \\
50\end{array}$ & [35] \\
\hline & & $\begin{array}{l}\text { Twin-screw extruder }\left(150-190^{\circ} \mathrm{C}, 100\right. \\
\text { rpm) }\end{array}$ & $0,5-2$ & $<2,5 \times 10^{-1}$ & [36] \\
\hline & \multirow{2}{*}{ Graphene } & $\begin{array}{l}\text { Twin-screw mixer }\left(175^{\circ} \mathrm{C}, 60 \mathrm{rpm}, 8\right. \\
\text { menit })\end{array}$ & $\begin{array}{c}0,2 \\
2\end{array}$ & $\begin{array}{l}1 \times 10^{-13} \\
1 \times 10^{-9} \\
\end{array}$ & {$[19]$} \\
\hline & & $\begin{array}{l}\text { Internal mixer }\left(180^{\circ} \mathrm{C}, 80 \mathrm{rpm}, 10\right. \\
\text { menit })\end{array}$ & $\begin{array}{l}1 \\
5\end{array}$ & $\begin{array}{l}5,6 \times 10^{-14} \\
2,6 \times 10^{-4}\end{array}$ & {$[37]$} \\
\hline & Graphite & $\begin{array}{l}\text { Twin-screw extruder }(160,170,180 \text {, } \\
\left.190,190,160 \text {, and } 155^{\circ} \mathrm{C}, 40 \mathrm{rpm}\right)\end{array}$ & 25 & $1 \times 10^{5}$ & [38] \\
\hline
\end{tabular}




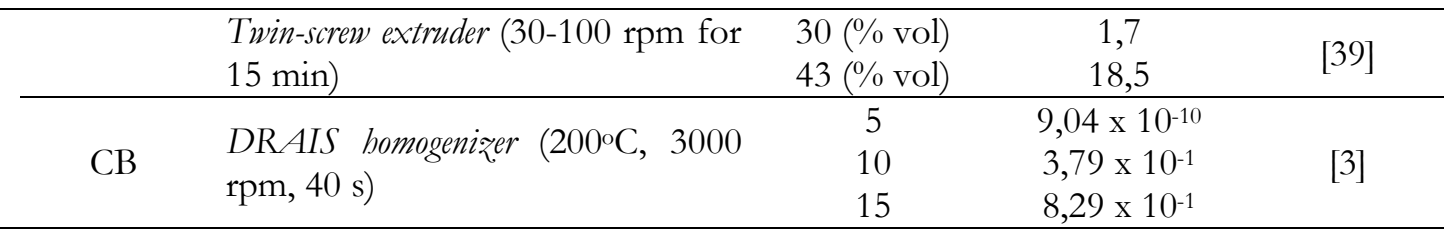

\subsection{Sifat Mekanik Komposit}

Nilai tensile strenght CPC dengan empat macam bahan isian jenis karbon yang diperoleh dari berbagai jurnal penelitian disajikan pada Tabel 3.

Tabel 3. Sifat Mekanik Komposit dengan Matriks PLA dan Bahan Isian Karbon

\begin{tabular}{|c|c|c|c|c|c|}
\hline Metode & $\begin{array}{l}\text { Bahan } \\
\text { Isian }\end{array}$ & Prosedur & $\begin{array}{l}\text { Komposisi } \\
\text { (\% berat) }\end{array}$ & $\begin{array}{l}\text { Tensile } \\
\text { Strength } \\
\left(\mathrm{S} . \mathrm{m}^{-1}\right)\end{array}$ & Referensi \\
\hline \multirow{13}{*}{$\begin{array}{l}\text { Solvent } \\
\text { Blending }\end{array}$} & \multirow{3}{*}{$\mathrm{CNT}$} & \multirow{3}{*}{$\begin{array}{l}\text { Solution mixing, pelarut kloroform } \\
\left(35^{\circ} \mathrm{C}, 3 \mathrm{Jam}\right)\end{array}$} & 1 & 9 & \multirow{3}{*}{ [40] } \\
\hline & & & 2 & 9,7 & \\
\hline & & & 3 & 8,5 & \\
\hline & \multirow{3}{*}{ Graphene } & \multirow{3}{*}{$\begin{array}{l}\text { Solution mixing, pelarut kloroform } \\
100 \mathrm{~mL}\left(35^{\circ} \mathrm{C}, 3 \mathrm{Jam}\right)\end{array}$} & 10 & 13,78 & \multirow{3}{*}{ [41] } \\
\hline & & & 30 & 14,3 & \\
\hline & & & 50 & 44,6 & \\
\hline & \multirow{3}{*}{ Graphite } & \multirow{3}{*}{ Sonication $\left(60^{\circ} \mathrm{C}, 60\right.$ menit $)$} & 20 & 6,9 & \multirow{3}{*}{ [33] } \\
\hline & & & 25 & 7,01 & \\
\hline & & & 30 & 7,15 & \\
\hline & \multirow{4}{*}{$\mathrm{CB}$} & \multirow{4}{*}{$\begin{array}{l}\text { Sonication, pelarut } \\
\left(200^{\circ} \mathrm{C}, 15 \text { menit }\right)\end{array}$} & 5 & 8,6 & \multirow{4}{*}{ [42] } \\
\hline & & & 10 & 15,4 & \\
\hline & & & 15 & 16,6 & \\
\hline & & & 20 & 17,1 & \\
\hline \multirow{12}{*}{$\begin{array}{c}\text { Melt } \\
\text { Blending }\end{array}$} & \multirow{2}{*}{ CNT } & Twin-screw extruder $\left(180^{\circ} \mathrm{C}, 80 \mathrm{rpm}\right.$, & 0,5 & 50,8 & \multirow{2}{*}{ [36] } \\
\hline & & 5 menit) & 1 & 48,3 & \\
\hline & \multirow{5}{*}{ Graphene } & & 0,1 & 35,8 & \multirow{2}{*}{ [43] } \\
\hline & & 1 wnn-screw extruder $\left(160^{\circ} \mathrm{C}, 60 \mathrm{rpm}\right)$ & 0,3 & 41,07 & \\
\hline & & \multirow{3}{*}{ Twin-screw extruder $\left(180^{\circ} \mathrm{C}, 50 \mathrm{rpm}\right)$} & 0,2 & 9,78 & \multirow{3}{*}{ [44] } \\
\hline & & & 0,4 & 10,99 & \\
\hline & & & 0,6 & 10,48 & \\
\hline & \multirow{4}{*}{ Graphite } & Twin-screw extruder $(160,170,180$ & 5 & 39,33 & \multirow{2}{*}[38]{} \\
\hline & & $190,190,160$, and $\left.155^{\circ} \mathrm{C}, 40 \mathrm{rpm}\right)$ & 10 & 39,93 & \\
\hline & & \multirow{2}{*}{ Twin-screw extruder $\left(180^{\circ} \mathrm{C}, 60 \mathrm{rpm}\right)$} & 15 & 3,5 & \multirow{2}{*}{ [33] } \\
\hline & & & 30 & 6,5 & \\
\hline & $\mathrm{CB}$ & Twin-screw extruder $\left(180^{\circ} \mathrm{C}, 80 \mathrm{rpm}\right)$ & $\begin{array}{c}5 \\
10\end{array}$ & $\begin{array}{l}58,01 \\
60,32\end{array}$ & [45] \\
\hline
\end{tabular}

Empat jenis karbon yang digunakan memberikan tensile strength yang berbeda pula pada komposisi yang sama karena CB, CNT, graphite, dan graphene murni memiliki tensile strenght yang berbeda. Tensile strenght mengambarkan tegangan maksimum yang bisa ditahan oleh sebuah bahan ketika diregangkan atau ditarik sebelum bahan itu patah.

Studi tentang sifat mekanik CPC menunjukkan bahwa modulus young polimer biasanya meningkat dengan meningkatnya kandungan bahan isian [46]. Faktor metode sintesis juga berpengaruh terhadap sifat mekanik CPC dimana penggunaan Melt blending menyebabkan Modulus young meningkat dan membuat komposit menjadi lebih kaku, sedangkan metode Solvent blending membuat bahan isian lebih merata dalam matriks sehingga komposit lebih kuat dan tidak mudah patah. 


\section{Kesimpulan}

Poly(Lactic Acid) dipilih sebagai matriks polimer karena kemampuannya untuk terdegradasi di dalam tanah sehingga aman dan tidak menimbulkan racun bagi lingkungan, dan bahan isian yang digunakan adalah karbon, karena senyawa ini tidak beracun dan mudah diperoleh sehingga cocok digunakan sebagai bahan isian CPC. Jenis karbon yang berpotensi sebagai bahan isian CPC yaitu Carbon black (CB), Carbon Nanotube (CNT), Graphite, dan Graphene dengan karakteristik yang berbeda satu sama lain, dimana hal ini akan memberikan perbedaan sifat elektrik dan sifat mekanis pada CPC yang dihasilkan.

Sintesis CPC terdapat dua metode, yaitu Solvent blending dan Melt blending, dengan keunggulan Melt blending yaitu mudah, praktis, murah, dapat diaplikasikan pada berbagai bahan, serta ramah lingkungan karena tidak ada pelarut organik. Kelebihan metode Solvent blending adalah campuran yang lebih kuat dikarenakan disperse yang terjadi merata dan lebih baik.

\section{References}

[1] C. Huang, X. Qian, R. Yang, “Thermal conductivity of polymers and polymer nanocomposites," Mater. Sci. Eng. R Reports. 132 1-22 (2018). https://doi.org/10.1016/j.mser.2018.06.002.

[2] X. Chen, Y. Su, D. Reay, S. Riffat, "Recent research developments in polymer heat exchangers - A review," Renew. Sustain. Energy Rev. 60 1367-1386 (2016). https://doi.org/10.1016/j.rser.2016.03.024.

[3] T.F. da Silva, F. Menezes, L.S. Montagna, A.P. Lemes, F.R. Passador, "Preparation and characterization of antistatic packaging for electronic components based on poly(lactic acid)/carbon black composites," J. Appl. Polym. Sci. 136 1-8 (2019). https://doi.org/10.1002/app.47273.

[4] H. Quan, S.J. Zhang, J.L. Qiao, L.Y. Zhang, "The electrical properties and crystallization of stereocomplex poly(lactic acid) filled with carbon nanotubes," Polymer (Guildf). 53 4547-4552 (2012). https://doi.org/10.1016/j.polymer.2012.07.061.

[5] W. Groot, J. Van Krieken, O. Sliekersl, S. De Vos, "Production and Purification of Lactic Acid and Lactide," Poly(Lactic Acid) Synth. Struct. Prop. Process. Appl. 3-18 (2010). https://doi.org/10.1002/9780470649848.ch1.

[6] M.A. Paul, C. Delcourt, M. Alexandre, P. Degée, F. Monteverde, P. Dubois, "Polylactide/montmorillonite nanocomposites: Study of the hydrolytic degradation," Polym. Degrad. Stab. 87 535-542 (2005). https://doi.org/10.1016/j.polymdegradstab.2004.10.011.

[7] G.M. Ganjyal, R. Weber, M.A. Hanna, "Laboratory composting of extruded starch acetate and poly lactic acid blended foams," Bioresour. Technol. $98 \quad 3176-3179$ (2007). https://doi.org/10.1016/j.biortech.2006.10.030.

[8] F. Mai, Y. Habibi, J.M. Raquez, P. Dubois, J.F. Feller, T. Peijs, E. Bilotti, "Poly(lactic acid)/carbon nanotube nanocomposites with integrated degradation sensing," Polymer (Guildf). 54 6818-6823 (2013). https://doi.org/10.1016/j.polymer.2013.10.035.

[9] S. Iannace, A. Maffezzoli, G. Leo, L. Nicolais, "Influence of crystal and amorphous phase morphology on hydrolytic degradation of PLLA subjected to different processing conditions," Polymer (Guildf). 42 3799-3807 (2001). https://doi.org/10.1016/S0032-3861(00)00744-8.

[10] S.M. Jaseem, N.A. Ali, "Antistatic packaging of carbon black on plastizers biodegradable polylactic acid nanocomposites," J. Phys. Conf. Ser. 1279 (2019). https://doi.org/10.1088/17426596/1279/1/012046.

[11] K. Li, K. Dai, X. Xu, G. Zheng, C. Liu, J. Chen, C. Shen, “Organic vapor sensing behaviors of carbon black/poly (lactic acid) conductive biopolymer composite," Colloid Polym. Sci. 291 2871-2878 (2013). https://doi.org/10.1007/s00396-013-3038-2.

[12] J.S. Leng, W.M. Huang, X. Lan, Y.J. Liu, S.Y. Du, "Significantly reducing electrical resistivity by forming conductive Ni chains in a polyurethane shape-memory polymer/carbon-black composite," Appl. Phys. Lett. 92 (2008). https://doi.org/10.1063/1.2931049.

[13] A. Sarafpour, G. Pircheraghi, R. Rashedi, K. Afzali, "Correlation between isothermal crystallization and morphological/rheological properties of bimodal polyethylene/carbon black systems," Polym. Cryst. 1 1-11 (2018). https:// doi.org/10.1002/pcr2.10014.

[14] D.D. Tune, B.S. Flavel, R. Krupke, J.G. Shapter, "Carbon nanotube-silicon solar cells," Adv. Energy Mater. 2 1043-1055 (2012). https://doi.org/10.1002/aenm.201200249.

[15] F. Mai, H. Deng, W. Tu, S. Chankajorn, Q. Fu, E. Bilotti, T. Peijs, "Oriented Poly(lactic acid)/Carbon 
Nanotube Composite Tapes with High Electrical Conductivity and Mechanical Properties," Macromol. Mater. Eng. 300 1257-1267 (2015). https://doi.org/10.1002/mame.201500163.

[16] M. Inagaki, Y. Kaburagi, Y. Hishiyama, "Thermal management material: Graphite," Adv. Eng. Mater. 16 494-506 (2014). https://doi.org/10.1002/adem.201300418.

[17] J.G. Speight, "Chapter 17 Coke, Carbon Black, and Graphite," Handb. Pet. Prod. Anal. Second Ed. 182 1-350 (2015).

[18] M.A. Worsley, P.J. Pauzauskie, T.Y. Olson, J. Biener, J.H. Satcher, T.F. Baumann, "Reference Guide Agilent Technologies 8753ES Option 011 Network Analyzer Regulatory and Warranty Information," $\begin{array}{lllll}\text { J. Am. Chem. Soc. } & \text { 14067-14069 }\end{array}$ http:/ /www.keysight.com/upload/cmc_upload/All/6C0608753-90480-08-121999.pdf?\&cc $=$ GB\&lc $=$ eng.

[19] C. Bao, L. Song, W. Xing, B. Yuan, C.A. Wilkie, J. Huang, Y. Guo, Y. Hu, "Preparation of graphene by pressurized oxidation and multiplex reduction and its polymer nanocomposites by masterbatchbased melt blending," J. Mater. Chem. 22 6088-6096 (2012). https://doi.org/10.1039/c2jm16203b.

[20] J.S.F. Barrett, A.A. Abdala, F. Srienc, "Poly(hydroxyalkanoate) elastomers and their graphene nanocomposites," Macromolecules. 47 3926-3941 (2014). https://doi.org/10.1021/ma500022x.

[21] H. Fallahi, H. Azizi, I. Ghasemi, M. Karrabi, "Preparation and properties of electrically conductive, flexible and transparent silver nanowire/poly (lactic acid) nanocomposites," Org. Electron. 44 74-84 (2017). https://doi.org/10.1016/j.orgel.2017.01.043.

[22] B. Kumar, M. Castro, J.F. Feller, "Poly(lactic acid)-multi-wall carbon nanotube conductive biopolymer nanocomposite vapour sensors," Sensors Actuators, B Chem. 161 621-628 (2012). https://doi.org/10.1016/j.snb.2011.10.077.

[23] O. Bianchi, L.G. Barbosa, G. MacHado, L.B. Canto, R.S. Mauler, R.V.B. Oliveira, "Reactive melt blending of PS-POSS hybrid nanocomposites," J. Appl. Polym. Sci. 128 811-827 (2013). https:// doi.org/10.1002/app.38196.

[24] F. Ali, R.J. Awale, M.E. Saeed Mirghani, H. Anuar, N. Samat, "Preparation and characterization of plasticized polylactic acid/starch blend," J. Teknol. 78 7-12 (2016). https://doi.org/10.11113/jt.v78.9936.

[25] S.N.B. Esmaeil Narimissa, Rahul K. Gupta, Nhol Kao, Hyoung Jin Choi, “The comparison between the effects of solvent casting and melt intercalation mixing processes on different characteristics of polylactide-nanographite platelets composites," Polym. Eng. Sci. 55 1560-1570 (2015). https:// doi.org/10.1002/pen.23996.

[26] K.M.Z. Hossain, R.M. Felfel, P.S. Ogbilikana, D. Thakker, D.M. Grant, C.A. Scotchford, I. Ahmed, "Single Solvent-Based Film Casting Method for the Production of Porous Polymer Films," Macromol. Mater. Eng. 303 1-7 (2018). https://doi.org/10.1002/mame.201700628.

[27] S. Il Moon, F. Jin, C.J. Lee, S. Tsutsumi, S.H. Hyon, "Novel carbon nanotube/poly(L-lactic acid) nanocomposites; their modulus, thermal stability, and electrical conductivity," Macromol. Symp. 224 287-296 (2005). https://doi.org/10.1002/masy.200550625.

[28] H.S. Kim, Y.S. Chae, B.H. Park, J.S. Yoon, M. Kang, H.J. Jin, "Thermal and electrical conductivity of poly(l-lactide)/multiwalled carbon nanotube nanocomposites," Curr. Appl. Phys. 8 803-806 (2008). https://doi.org/10.1016/j.cap.2007.04.032.

[29] H.-C.W. Wei-Ming Chiu,You-An Chang,Hsan-Yuan Kuo,Meng-Hung Lin, "A study of carbon nanotubes/biodegradable plastic polylactic acid composites," J. Appl. Polym. Sci. 108 3024-3030 (2008). https:// doi.org/10.1002/app.27796.

[30] W.M. Chiu, H.Y. Kuo, P.A. Tsai, J.H. Wu, "Preparation and Properties of Poly (Lactic Acid) Nanocomposites Filled with Functionalized Single-Walled Carbon Nanotubes," J. Polym. Environ. 21 350-358 (2013). https://doi.org/10.1007/s10924-012-0514-6.

[31] X.Z. Tong, F. Song, M.Q. Li, X.L. Wang, I.J. Chin, Y.Z. Wang, "Fabrication of graphene/polylactide nanocomposites with improved properties," Compos. Sci. Technol. 88 33-38 (2013). https://doi.org/10.1016/j.compscitech.2013.08.028.

[32] Y. Shen, T. Jing, W. Ren, J. Zhang, Z.G. Jiang, Z.Z. Yu, A. Dasari, "Chemical and thermal reduction of graphene oxide and its electrically conductive polylactic acid nanocomposites," Compos. Sci. Technol. 72 1430-1435 (2012). https://doi.org/10.1016/j.compscitech.2012.05.018.

[33] N.M. Abdullah, A.Z.M. Rus, M.F.L. Abdullah, "Enhancement of graphite functionality in renewable polymer composite properties," Int. J. Eng. Technol. 7 215-220 (2018). 
https://doi.org/10.14419/ijet.v7i3.14.16896.

[34] G. Gorrasi, A. Sorrentino, "Photo-oxidative stabilization of carbon nanotubes on polylactic acid," Polym. Degrad. Stab. 98 963-971 (2013). https://doi.org/10.1016/j.polymdegradstab.2013.02.012.

[35] P. Pötschke, T. Andres, T. Villmow, S. Pegel, H. Brünig, K. Kobashi, D. Fischer, L. Häussler, "Liquid sensing properties of fibres prepared by melt spinning from poly(lactic acid) containing multi-walled carbon nanotubes," Compos. Sci. Technol. $70 \quad 343-349 \quad$ (2010). https://doi.org/10.1016/j.compscitech.2009.11.005.

[36] R.M. Novais, F. Simon, P. Pötschke, T. Villmow, J.A. Covas, M.C. Paiva, "Poly(lactic acid) composites with poly(lactic acid)-modified carbon nanotubes," J. Polym. Sci. Part A Polym. Chem. 51 3740-3750 (2013). https://doi.org/10.1002/pola.26778.

[37] L. Lei, J. Qiu, E. Sakai, "Preparing conductive poly(lactic acid) (PLA) with poly(methyl methacrylate) (PMMA) functionalized graphene (PFG) by admicellar polymerization," Chem. Eng. J. 209 20-27 (2012). https://doi.org/10.1016/j.cej.2012.07.114.

[38] R. Guo, Z. Ren, H. Bi, M. Xu, L. Cai, "Electrical and thermal conductivity of polylactic Acid (PLA)based biocomposites by incorporation of nano-graphite fabricated with fused deposition modeling," Polymers (Basel). 11 (2019). https://doi.org/10.3390/polym11030549.

[39] J. Tolvanen, J. Hannu, M. Hietala, K. Kordas, H. Jantunen, "Biodegradable multiphase poly(lactic acid)/biochar/graphite composites for electromagnetic interference shielding," Compos. Sci. Technol. 181107704 (2019). https://doi.org/10.1016/j.compscitech.2019.107704.

[40] J. Alam, A. Khan, M. Alam, R. Mohan, "Electroactive shape memory property of a Cu-decorated CNT dispersed PLA/ESO nanocomposite," Materials (Basel). $8 \quad 6391-6400$ (2015). https://doi.org/10.3390/ma8095313.

[41] S.N.K. Mohamad, I. Ramli, L.C. Abdullah, N.H. Mohamed, M.S. Islam, N.A. Ibrahim, N.S. Ishak, "Evaluation on structural properties and performances of graphene oxide incorporated into chitosan/poly-lactic acid composites: Cs/pla versus cs/pla-go," Polymers (Basel). 13 (2021). https://doi.org/10.3390/polym13111839.

[42] B. Szadkowski, A. Marzec, M. Zaborski, "Use of carbon black as a reinforcing nano-filler in conductivity-reversible elastomer composites," Polym. Test. 81 (2020). https://doi.org/10.1016/j.polymertesting.2019.106222.

[43] B.W. Chieng, N.A. Ibrahim, W.M.Z. Wan Yunus, M.Z. Hussein, V.S.G. Silverajah, "Graphene nanoplatelets as novel reinforcement filler in poly(lactic acid)/epoxidized palm oil green nanocomposites: Mechanical Properties," Int. J. Mol. Sci. 13 10920-10934 (2012). https:// doi.org/10.3390/ijms130910920.

[44] M.M. Haidari, H. Kim, J.H. Kim, M. Park, H. Lee, J.S. Choi, "Doping effect in graphene-graphene oxide interlayer," Sci. Rep. 10 1-7 (2020). https://doi.org/10.1038/s41598-020-65263-y.

[45] X. Liu, T. Wang, L.C. Chow, M. Yang, J.W. Mitchell, "Effects of inorganic fillers on the thermal and mechanical properties of poly(lactic acid)," Int. J. Polym. Sci. 2014 (2014). https://doi.org/10.1155/2014/827028.

[46] M.A. Rafiee, J. Rafiee, Z. Wang, H. Song, Z.Z. Yu, N. Koratkar, "Enhanced mechanical properties of nanocomposites at low graphene content," ACS Nano. 3 3884-3890 (2009). https://doi.org/10.1021/nn9010472. 